\title{
PENGAWASAN OMBUDSMAN TERHADAP PENYELENGGARAAN PELAYANAN PUBLIK PADA MASA PANDEMI CORONA VIRUS DISEASE 2019 (COVID-19)
}

\author{
Inggit Akim \\ Fakultas Hukum, Universitas Borneo Tarakan \\ Tarakan, Kalimantan Utara, Indonesia \\ inggitakimfh@gmail.com
}

\begin{abstract}
Supervise the government as the provider of public services to carry out their duties and authorities under applicable regulations. Large-Scale Social Restrictions are restrictions on certain activities in an area suspected of being infected with Corona Virus Disease 2019 (COVID-19), which causes the quality of public services to be disrupted. The Ombudsman has the task of supervising the implementation of shared services organized by state or government officials and private or individual bodies assigned the task of providing services according to minimum service standards as a benchmark for service delivery and assessing the quality of services to the community. The research method used is normative juridical research with a conceptual approach (Statute Approach).

The results of this study are large-scale social restriction policies through the Mayor of Tarakan Regulation Number 17 of 2020, restrictions on activities outside the house such as the implementation of learning at schools and/or other educational institutions, Work From Home (WFH), religious movements in houses of worship, activities in public places, social and cultural activities and Mandatory rapid tests for those using Sea and Air transportation modes, and providing social assistance to communities affected by COVID-19. Ombudsman's supervision of public services during the COVID-19 pandemic in Tarakan City, namely by conducting coordination and control and cooperation with state and private officials as well as community or individual organizations, opening an Online Complaint Post for COVID-19 Affected Persons. Also, conduct unannounced checks to improve public services in the City of Tarakan. Based on the supervision, the receipt of reports on suspicion of maladministration and the Ombudsman's investigation results are subject to examination. Suppose it is proven that it has committed maladministration in public services, the Ombudsman of the Republic of Indonesia can take corrective action and provide recommendations/suggestions to state administrators to improve the quality of public services.
\end{abstract}

Keywords: Surveillance; Ombudsman; Public Service; COVID-19 Pandemic 


\begin{abstract}
ABSTRAK
Pengawasan terhadap pemerintah sebagai penyelenggara pelayanan publik agar dalam melaksanakan tugas dan wewenangnya sesuai dengan peraturan yang berlaku. Pembatasan Sosial Berskala Besar adalah pembatasan kegiatan tertentu dalam suatu wilayah yang diduga terinfeksi Corona Virus Disease 2019 (COVID-19) yang menyebabkan kualitas pelayanan publik terganggu. Ombudsman mempunyai tugas mengawasi penyelenggaraan pelayanan publik yang diselenggarakan oleh penyelenggara negara atau pemerintahan serta badan swasta atau perseorangan yang diberi tugas untuk menyelenggarakan pelayanan sesuai standar pelayanan minimal sebagai tolak ukur penyelenggaraan pelayanan dan penilaian kualitas pelayanan kepada masyarakat. Metode penelitian yang digunakan yaitu penelitian yuridis normatif dengan pendekatan (Statute Approach) pendekatan konsep (conseptual approach).

Hasil dari penelitian ini kebijakan Pembatasan Sosial Berskala Besar melalui Peraturan Walikota Tarakan Nomor 17 Tahun 2020, pembatasan aktivitas dilur rumah seperti pelaksanaan pembelajaran di Sekolah dan/atau institusi pendidikan lainnya, Work FromHome (WFH), kegiatan keagamaan di rumah ibadah, kegiatan ditempat umum, kegiatan sosial dan budaya dan Wajib rapid test bagi yang menggunakan moda transportasi Laut dan Udara, dan memberikan bantuan sosial kepada masyarakat yang terdampak COVID-19. Pengawasan Ombudsman terhadap pelayanan publik pada masa pandemi COVID-19 di Kota Tarakan yaitu dengan melakukan koordinasi dan Supervisi serta kerjasama dengan penyelenggara negara dan swasta serta lembaga kemasyarakatan atau perseorangan, membuka Posko Pengaduan Online bagi Warga Terdampak COVID-19. Juga melakukan pemeriksaan mendadak dalam rangka meningkatakan pelayanan publik di Kota Tarakan. Berdasarkan pengawasan, penerimaan laporan atas dugaan maladministrasi, dan hasil investigasi ombudsman dilakukan pemeriksaan. Apabila terbukti melakukan maladministrasi pelayanan publik, maka Ombudsman Republik Indonesia dapat melakukan tindakan korektif dan memberikan rekomendasi/saran kepada penyelenggara negara untuk meningkatan kualitas pelayanan publik.
\end{abstract}

Keywords: Pengawasan; Ombudsman; Pelayanan Publik; Pandemi COVID-19

\title{
PENDAHULUAN
}

Informasi dari World Health Organization (WHO) pada tanggal 31 Desember 2019 yang menyebutkan adanya kasus kluster pneumonia dengan etiologi yang tidak jelas di Kota Wuhan, Provinsi Hubei, China. Corona Virus Disease 2019 (COVID-19) merupakan keluarga besar virus yang menyebabkan penyakit pada manusia dan hewan. Berdasarkan data dari website COVID-19 pusat pertanggal 29 Oktober 2020 yang bersumber dari WHO tercatat secara global 219 Negara terkonfirmasi 44.002.003, meninggal 1.167.988. Indonesia tercatat terkonfirmasi positif sebanyak 404.048, sembuh 239.778 dan yang meninggal sejumlah 13.701 orang. Dari data tersebut secara global terkonfirmasi COVID- 
19 ada 219 negara termasuk Indonesia. Jumlah kasus COVID-19 dan kematian akibat COVID-19 di Indonesia semakin meningkat dan meluas di sejumlah wilayah di Indonesia. Akibat dari meluasnya penyebaran COVID-19 tersebut berdampak pada berbagai aspek kehidupan seperti politik, ekonomi, sosial, budaya, pertahanan dan keamanan serta kesejahteraan masyarakat Indonesia. Sebagai upaya pemerintah Indonesia untuk menekan lajunya penyebaran COVID-19 yaitu dengan Social Distancing dan Physical Distancing untuk mencegah terjadinya penyebaran COVID-19 lebih luas. Dengan diterapkannya Social Distancing/Physical Distancing di Indonesia, masyarakat diminta untuk tetap dirumah dan tidak boleh keluar rumah jika tidak ada keperluan yang penting atau mendesak.

Upaya menanggulangi penyebaran COVID-19 Pemerintah menerbitkan Peraturan Pemerintah Nomor 21 Tahun 2020 tentang Pembatasan Sosial Berskala Besar selanjutnya disingkat PP No. 21 Tahun 2020 dalam rangka percepatan penanganan COVID-19. Berdasarkan PP No. 21 Tahun 2020, Pasal 1 dijelaskan bahwa Pembatasan Sosial Berskala Besar merupakan pembatasan kegiatan tertentu dalam suatu wilayah yang diduga terinfeksi COVID-19. Kebijakan PSBB tersebut membatasi aktivitas masyarakat seperti peliburan tempat sekolah dan bekerja ditempat kerja, pembatasan kegiatan keagamaan, pembatasan kegiatan difasilitas umum. Pemerintah juga menghimbau penerapan Work From Home (WFH) bagi ASN dan Perusahaan Swasta yang pekerjaannya dimungkinkan dilakukan dari rumah, menganjurkan untuk tidak bepergian serta melarang kegiatan yang mengumpulkan massa.

Undang-Undang Nomor 25 Tahun 2009 tentang Pelayanan Publik selanjutnya disingkat UU No. 25 Tahun 2009, Pasal 1 Angka 1 Pelayanan publik adalah kegiatan atau rangkaian kegiatan dalam rangka pemenuhan kebutuhan pelayanan sesuai dengan peraturan perundang-undangan bagi setiap warga negara dan penduduk atas barang, jasa, dan/atau pelayanan administratif yang disediakan oleh penyelenggara pelayanan publik. Ketentuan mengenai Pelayanan Publik, masyarakat adalah sebagai pihak yang memiliki hak dan kewajiban dalam mewujudkan pelayanan publik, demikian juga dengan penyelenggara layanan memiliki hak dan kewajiban yang samadengan masyarakat dalam mewujudkan pelayanan publik. Ombudsman adalah lembaga negara yang mempunyai 
kewenangan mengawasi penyelenggaraan pelayanan publik yang diselenggarakan oleh penyelenggaran negara dan pemerintahan serta badan swasta atau perseorangan yang diberi tugas untuk menyelenggarakan pelayanan publik tertentu yang sebagian atau seluruh dananya bersumber dari anggaran pendapatan dan belanja negara (APBN) dan/atau anggaran pendapatan dan belanja daerah (APBD).

Ombudsman Republik Indonesia Perwakilan Kalimantan Utara telah menerima laporan/pengaduan masyarakat atas dugaan maladministrasi dalam pelayanan publik terkait pelayanan administrasi kependudukan, pelayanan PLN, perpajakan, perizinan, keimigrasian dan minyak dan gas pada masa pandemic COVID-19 ini.

Berdasarkan latar belakang diatas dipandang perlu untuk melakukan penelitian tentang Pengawasan Ombudsman terhadap Penyelenggaraan Pelayanan Publik pada Masa Pandemi Corona Virus Disease 2019 (COVID-19) dengan rumusan masalah pada penelitian ini yaitu

1) Kebijakan Pemerintah dalam Penerapan Pembatasan Sosial Berskala Besar

2) Pengawasan Ombudsman Terhadap Penyelenggaraan Pelayanan Publik pada Masa Pandemi Corona Virus Disease 2019 (COVID-19) di Kota Tarakan

Tujuan Penelitian ini adalah untuk memberikan pemahaman mengenai Kebijakan Pemerintah dalam Penerapan Pembatasan Sosial Berskala Besar dan Pengawasan Ombudsman Terhadap Penyelenggaraan Pelayanan Publik pada Masa Pandemi Corona Virus Disease 2019 (COVID-19) di Kota Tarakan.

\section{METODE PENELITIAN}

Penelitian dalam tulisan ini adalah penelitian hukum yuridis-normatif. Penelitian ini menggunakan pendekatan perudang-undang (Statute Approach) yaitu dengan menelaah semua undang-undang dan regulasi yang bersangkut paut dengan isu hukum yang sedang diteliti. Dan pendekatan konsep (conseptual approach) yakni dengan mempelajari pandangan-pandangan dan doktrin-doktrin didalam ilmu hukum, peneliti akan menemukan ide-ide yang melahirkan pengertian-pengertian hukum, konsep-konsep hukum dan asas-asas hukum yang relevan dengan isu yang dihadapi serta sebagai 
sandaran dalam membangun suatu argumentasi hukum dalam memecahkan isu yang dihadapi. Dengan pendekatan yang dilakukan ini hingga ditemukan suatu upaya pembenahan dan pendekatan baru guna menanggulangi permasalahan yang ada. ${ }^{1}$ Untuk mendukung peneliti dalam penelitian ini juga melakukan wawancara dengan pihak yang berwenang dalam hal ini Lembaga Ombudsman perwakilan Kalimantan Utara. Berdasarkan uraian diatas peneliti ingin melakukan penelitian terkait Kebijakan Pemerintah dalam Penerapan PSBB dan Pengawasan Ombudsman Terhadap Penyelenggaraan Pelayanan Publik pada Masa Pandemi Corona Virus Disease 2019 (COVID-19) di Kota Tarakan.

\section{PEMBAHASAN}

\section{A. Kebijakan Pemerintah dalam Penerapan Pembatasan Sosial Berskala Besar.}

Berdasarkan Penjelasan Peraturan Pemerintah Nomor 25 Tahun 2000 Tentang Kewenangan Pemerintah dan Provinsi Sebagai Daerah Otonom dijelaskan pada pasal 2 ayat (3) huruf a bahwa kebijakan adalah pernyataan prinsip sebagai landasan pengaturan dalam pencapaian suatu sasaran. Selain itu dijelaskan juga dalam Peraturan Pemerintah Nomor 8 Tahun 2008 tentang Tahapan, Tata Cara Peyusunan Pengendalian dan Evaluasi Pelaksanaan Pembangunan Daerah yang terdapat pada pasal 1 angka 12 bahwa kebijakan adalah arah atau tindakan yang diambil oleh pemerintah daerah untuk mencapai tujuan.

Kebijakan menurut James E. Anderson, yaitu serangkaian tindakan yang mempunyai tujuan tertentu yang diikuti dan dilaksanakan oleh seseorang pelaku atau kelompok pelaku guna memecahkan suatu masalah tertentu. Istilah kebijakan publik lebih sering dipergunakan dalam kaitannya dengan tindakan-tindakan atau kegiatan pemerintah. ${ }^{2}$ Sebagai keputusan yang mengikat publik, kebijakan publik harus dibuat oleh otoritas politik, yaitu mereka yang menerima mandat dari publik atau orang banyak, umumnya memalui suatu proses pemilihan untuk bertindak atas nama rakyat banyak. Selanjutnya kebijakan publik akan dilaksanakan oleh administrasi negara yang dijalankan oleh birokrasi pemerintah. ${ }^{3}$ Kebijakan publik di negara modern yang jadi fokus utama adalah

\footnotetext{
1 Peter Mahmud Marzuki, 2016, Penelitian Hukum, Jakarta: Prenadamedia Group, hal. 133 2Islamy, Prinsip-prinsip Perumusan Kebijakan Negara, Bumi Aksara, Jakarta1997, hal. 67. 3 Sahya Anggara, 2014. Kebijakan Publik, Pustaka Setia, Bandung. hal,33
} 
pelayanan publik, yaitu segala sesuatu yang bisa dilakukan oleh negara untuk mempertahankan atau meningkatkan kualitas kehidupan orang banyak. Menyeimbangkan peran negara yang mempunyai kewajiban menyediakan pelayanan publik dengan hak untuk menarik pajak dan retribusi dan menyeimbangkan berbagai kelompok dalam masyarakat dengan berbagai kepentingan serta mencapai amanat konstitusi. ${ }^{4}$ Berdasarkan pendapat tersebut bahwa kebijakan publik yang dilakukan oleh pemerintah merupakan suatu tindakan yang dilakukan dalam rangka mencapai tujuan untuk kepentingan masyarakat.

Penyebaran Corona Virus Disease 2019 (COVID-19) di Indonesia saat semakin meningkat dan meluas lintas wilayah dan lintas negara yang diiringi dengan jumlah kasus dan/atau jumlah kematian. Berdasarkan data dari website COVID-19 pusat pertanggal 29 Oktober 2020 yang bersumber dari WHO tercatat secara global 219 Negara terkonfirmasi 44.002.003, meninggal 1.167.988. Indonesia tercatat terkonfirmasi positif sebanyak 404.048, sembuh 239.778 dan yang meninggal sejumlah 13.701 orang. ${ }^{5}$ Data tersebut menunjukan bahwa ada peningkatan terkonfitmasi positif COVID-19 di Indonesia. Sementara di Kota Tarakan Provinsi Kalimantan Utara berdasarkan data update Gugus Tugas Percepatan Penanganan COVID-19 Kota Tarakan total konfirmasi per tanggal 6 Oktober 2020 sebanyak 388 orang. Dari data tersebut meningkat dari sebelumnya adalah 385 orang yang jumlah terkonfirmasi semakin hari terus bertambah. Peningkatan tersebut berdampak pada aspek politik, ekonomi, sosial, budaya, pertahanan dan keamanan, serta kesejahteraan masyarakat di Indonesia, sehingga diperlukan percepatan penanganan Corona Virus Disease 2019 (COVID-19) dalam bentuk tindakan Pembatasan Sosial Berskala Besar dalam rangka menekan penyebaran Corona Virus Disease 2019 (COVID19) semakin meluas.

Pemerintah mengeluarkan Keputusan Presiden Nomor 11 Tahun 2020 tentang Penetapan Kedaruratan Kesehatan Masyarakat, Peraturan Pemerintah Nomor 21 Tahun 2020 tentang Pembatasan Sosial Berskala Besar Dalam Rangka Percepatan Penanganan Covid 19 selanjutnya disingkat PP NO. 21 Tahun 2020 tentang PSBB. PSBB yang merupakan

${ }^{4}$ Ibid. hal. 33

5 https://www.covid19.go.id/

6| Universitas Borneo Tarakan 
tindak lanjut dari ketentuan Pasal 15 Ayat (2) dan Pasal 56 Undang Undang Nomor 6 Tahun 2018 tentang Kekarantinaan Kesehatan, Undang-Undang Nomor 36 Tahun 2009 tentang Kesehatan dan Undang-Undang Nomor 4 Tahun 1984 tentang Wabah Penyakit Menular.

PSBB merupakan kebijakan pemerintah yang pembatasan kegiatan tertentu penduduk dalam suatu wilayah yang diduga terinfeksi COVID-19 sedemikian rupa untuk mencegah kemungkinan penyebarannya meliputi pembatasan terhadap pergerakan orang dan/atau barang untuk satu provinsi atau kabupaten/kota tertentu. Dalam Peraturan Pemerintah ini mengatur pelaksanaannya yang ditetapkan oleh Menteri Kesehatan dan dapat dilakukan oleh Pemerintah Daerah berdasarkan persetujuan Menteri Kesehatan.

Berdasarkan Pasal 2 Ayat (1) dan (2) PP No. 21 Tahun 2020, Dengan persetujuan menteri yang menyelenggarakan urusan pemerintahan dibidang kesehatan, Pemerintah Daerah dapat melakukan Pembatasan Sosial Berskala Besar atau pembatasan terhadap pergerakan orang dan barang untuk satu provinsi atau kabupaten/kota tertentu" dan Pembatasan Sosial Berskala Besar sebagaimana dimaksud pada ayat (1) harus didasarkan pada pertimbangan epidemiologis, besarnya ancaman, efektifitas, dukungan sumber daya, teknis operasional, pertimbangan politik, ekonomi, sosial, budaya, pertahanan dan keamanan.6 Daerah dapat melakukan PSBB atas izin menteri yang menyelenggarakan urusan kesehatan. Dan Menteri Kesehatan menetapkan status PSBB yang diusulkan Gubernur, Walikota, atau Bupati di wilayah mereka masing-masing.

Berdasarkan Keputusan Menteri Kesehatan Republik Indonesia Nomor HK.01.07 /MENKES/261/2020 telah ditetapkan Pembatasan Sosial Berskala Besar diwilayah Kota Tarakan Provinsi Kalimantan Utara dalam rangka percepatan penanganan Corona Virus Disease 2019 (COVID-19). Walikota Tarakan dalam rangkan penerapan PSBB di daerah kemudian menerbitkan Peraturan Wali Kota Nomor 17 Tahun 2020 tentang Pelaksanaan Pembatasan Sosial Berskala Besar Dalam rangka percepatan Penanganan Corona Virus Disease 2019 (COVID-19) di Kota Tarakan sebagai upaya pemerintah untuk mencegah meluasnya penyebaran COVID-19 dalam bentuk pembatasan aktivitas luar rumah yang

6 Pasal 2 (1) Peraturan Pemerintah Nomor 21 Tahun 2020 tentang Pembatasan Sosial Berskala Besar Dalam Rangka Percepatan Penanganan Corona Virus Disease 2019 (COVID-19) 
dilakukan oleh setiap orang yang berdomisili dan/atau berkegiatan di Kota Tarakan. Pasal 3 Peraturan Wali Kota Nomor 17 Tahun 2020 ini bertujuan untuk: ${ }^{7}$ membatasi kegiatan tertentu dan pergerakan orang dan/ atau barang dalam menekan penyebaran Corona Virus Disease 2019 (COVID-19); meningkatkan antisipasi perkembangan ekskalasi penyebaran Corona Virus Disease 2019 (COVID-19), memperkuat upaya penanganan kesehatan akibat CoronaVirus Disease 2019 (COVID-19), dan menangani dampak sosial dan ekonomi dari penyebaran Corona Virus Disease 2019 (COVID-19). Berdasarkan kebijakan tersebut pemerintah Kota Tarakan melaksanakan pembatasan sebagai berikut:

a. Pembatasan Pelaksanaan Pembelajaran di Sekolah dan/atau Institusi Pendidikan Lainnya. Selama pemberlakuan PSBB, dilakukan penghentian sementara kegiatan di sekolah.

b. Pembatasan Aktivitas bekerja ditempat kerja Work From Home (WFH). Pemerintah telah melakukan berbagai upaya dan kebijakan, salah satunya adalah bekerja dari rumah atau Work From Home (WFH) bagi Aparatur Sipil Negara (ASN), yaitu melaksanakan tugas kedinasan di rumah/tempat tinggalnya masing-masing untuk mencegah dan meminimalisir penyebaran COVID-19. Aparatur Sipil Negara (ASN) di pusat dan daerah termasuk di Kota Tarakan menerapkan kebijakan bekerja dari rumah atau WFH. Dengan demikian tidak ada pelayanan secara langsung di loket instansi dan layanan langsung dibatasi sesuai dengan protokol kesehatan. Hal tersebut berdampak pada pelayan publik yang kurang maksimal. Tetapi pemerintah juga melakukan inovasi dalam memberikan layanan yaitu dalam jaringan atau online atau Virtual.

c. Kegiatan keagamaan dirumah ibadah. Berdasarkan Surat Edaran Menteri Agama Nomor 15 Tahun 2020 Tentang Panduan Penyelenggaraan Kegiatan Keagamaan di Rumah Ibadah Dalam Mewujudkan Masyarakat Produktif dan Aman Covid di Masa Pandemi maka Walikota Tarakan juga mengeluarkan Surat Edaran Nomor 180/383/Hukum/2020 tentang Penyelenggaraan Kegiatan keagamaan diRumah Ibadah dalam masa Penataan Kembali Kehidupan

\footnotetext{
7 Peraturan Wali Kota Nomor 17 Tahun 2020 tentang Pelaksanaan Pembatasan Sosial Berskala Besar Dalam rangka percepatan Penanganan Corona Virus Disease 2019 (COVID-19) di Kota Tarakan
}

8 | Universitas Borneo Tarakan 
d. Kegiatan ditempat umum. Selama pemberlakuan PSBB, penduduk dilarang melakukan kegiatan dengan jumlah lebih dari 5 (lima) orang ditempat atau fasilitas umum. Pengelola tempat atau fasilitas umum wajib menutup sementara tempat atau fasilitas umum untuk kegiatan penduduk selama pemberlakuan PSBB. Kecuali kegiatan penduduk untuk memenuhi kebutuhan pokok dan/atau kebutuhan sehari-hari.

e. Kegiatan sosial dan budaya. Penghentian sementara atas kegiatan sosial dan budaya yang menimbulkan kerumunan orang seperti kegiatan politik, olahraga, hiburan, kegiatan akademik, dan budaya. Kecuali kegiatan khitan, pernikahan, pemakaman kematian bukan karena CIVID-19.

f. Pergerakan orang dan barang menggunakan moda transportasi. Semua kegiatan selama pemberlakuan PSBB, pergerakan orang dan/atau barang dihentikan sementara kecuali untuk pemenuhan kebutuhan pokok, kegiatan lain khusus terkait aspek pertahanan dan keamanan, kegiatan yang diperbolehkan.

Kebijakan wajib rapid test sebagai persyaratan mobilisasi masyarakat di wilayah Kaltara. Rapid Test sebagai persyaratan proses mobilisasi masyarakat. sebelum adanya aturan Kementerian Kesehatan melalui Surat Edaran (SE) mengenai batasan tarif Rapid Test antibodi untuk Corona (COVID-19) yang mana tarif tertinggi Rapid Test diatur Rp 150.000 melalui SE Nomor HK.02.02/I/2875/2020 yang ditetapkan 6 Juli 2020. Terdapat beberapa dugaan maladministrasi dalam penerapan kebijakan Rapid Test. Dan memberikan bantuan sosial kepada masyarakat Kota Tarakan yang terdampak dari COVID19 dalam bentuk sembako.

Penerapan kebijakan PSBB dari satu sisi baik dengan tujuan untuk mengurang lajunya penyebaran COVID-19, namun disi lain kebijakan yang membatasi kegiatan masyarakat sehingga mengakibatkan pelayanan publik baik pemerintah maupun swasta kepada masyarakat terganggu dan tidak sesuai dengan standar pelayanan minimal terbukti dengan masih adanya keluhan dan laporan dari masyarakat terkait adanya dugaan pelanggaran pelayanan publik kepada Ombudsman sebagai lembaga yang berwenang dan bertugas mengawasi penyelenggaraa pelayanan publik. 


\section{B. Pengawasan Ombudsman terhadap pelayanan publik pada masa pandemi COVID- 19 di Kota Tarakan.}

Upaya untuk meningkatkan kualitas dan menjamin penyediaan pelayanan publik sesuai dengan asas-asas umum pemerintahan yang baik dan untuk memberi perlindungan bagi setiap warga negara dan penduduk dari penyalahgunaan wewenang dalam penyelenggaraan pelayanan publik, diperlukan pengaturan hukum yang mendukungnya. Pelayanan publik merupakan sebuah kewajiban bagi pemerintah, namun sebaliknya menjadi hak bagi masyarakat. Untuk memperolehdan menyelenggarakan pelayanan publik yang baik, maka setidak-tidaknya pelayanan publik tersebut harus memiliki standar minimal yang harus diisyaratkan agar supaya memenuhi harapan masyarakat. 8 Pemerintah menerbitkan Undang-undang Nomor 25 Tahun 2009 tentang Pelayanan Publik delanjutnya disingkat UU No.25/2009 dengan tujuan:

1. terwujudnya batasan dan hubungan yang jelas tentang hak, tanggung jawab, kewajiban, dan kewenangan seluruh pihak yang terkait dengan penyelenggaraan pelayanan publik;

2. terwujudnya sistem penyelenggaraan pelayanan publik yang layak sesuai dengan asasasas umum pemerintahan dan korporasi yang baik; terpenuhinya penyelenggaraan pelayanan publik sesuai dengan peraturan perundang-undangan;

3. dan terwujudnya perlindungan dan kepastian hukum bagi masyarakat dalam penyelenggaraan pelayanan publik.

Pasal 5 UU No. 25 Tahun 2009, Ruang lingkup pelayanan publik meliputi pelayanan barang publik dan jasa publik serta pelayanan administratif yang diatur dalam peraturan perundang-undangan. Pasal 5 ayat (1) salah satu ruang lingkup pelayanan publik adalah pelayanan dibidang administratif. Pelayanan publik adalah kegiatan melayani masyarakat dalam memenuhi kebutuhan hidup baik dari barang, jasa dan/atau pelayanan administratif yang dapat dilakukan pada ditempat-tempat penyelenggaraan pelayanan publik. Pelayanan publik haruslah memiliki Standar Pelayanan (SP) dan Standar Oprasional Prosedur (SOP) yang telah ditetapkan. Dalam Pasal 12 huruf (d) PP Nomor 96 Tahun 2012, sistem

${ }^{8}$ Husni Thamrin, Hukum Pelayanan Publik di Indonesia, Aswaja Pressindo, Yogyakarta, 2013, hal. 25. 
pelayanan terpadu diselenggarakan dengan tujuan mewujudkan proses pelayanan yang cepat, mudah, murah, transparan, pasti, dan terjangkau. Sebagaimana diuraikan di atas bahwa untuk menciptakan pemerintahan yang bersih, salah satunya adalah dengan melaksanakan pelayanan publik yang baik. Untuk melakukan pelayanan tersebut tentu harus berpegang pada peraturan yang berlaku dan juga perlu adanya pengawasan. Good Government akan dapat terlaksana sepenuhnya apabila ada keinginan keinginan kuat (political will) penyelenggara pemerintah dan penyelenggara negara untuk berpegang teguh pada peraturan perundangan dan kepatutan, namun yang sangat mendasar yaitu adanya kerelaan para penyelenggara pemerintahan serta penyelenggara negara untuk bersedia dikontrol dan diawasi, baik secara internal dan ekternal. ${ }^{9}$

UU No. 25 Tahun 2009, Ombudsman merupakan salah satu lembaga pengawas ekternal selain pengawasan masyarakat dan pengawasan DPR/DPRD yang berhak untuk melakukan pengawasan pelayanan publik. Seseuai Pasal 35 ayat 3 menyebutkan "pengawasan eksternal penyelenggaraan pelayanan publik dilakukan melalui":

1. pengawasan oleh masyarakat berupa laporan atau pengaduan masyarakat dalam penyelenggaraan pelayanan publik;

2. pengawasan oleh ombudsman sesuai dengan peraturan perundang-undangan;

3. pengawasan oleh dewan perwakilan rakyat, dewan perwakilan rakyat daerah propinsi, dewan perwakilan rakyat daerah kabupaten/kota.

Undang-Undang Republik Indonesia Nomor 37 Tahun 2008 Tentang Ombudsman Republik Indonesia selanjutnya disingkat UU No. 37 Tahun 2008. Pasal 1 UU No. 37 Tahun 2008, Ombudsman Republik Indonesia yang selanjutnya disebut Ombudsman adalah Lembaga Negara yang mempunyai kewenangan mengawasi Penyelenggaraan Pelayanan Publik baik yang diselenggarakan oleh penyelenggara Negara dan pemerintahan termasuk yang diselenggarakan oleh Badan Usaha Miliki Negara, Badan Usaha Milik Daerah, dan Badan Hukum milik Negara serta Badan Swasta atau perseorangan yang diberi tugas menyelenggarakan pelayanan publik tertentu yang sebagian atau seluruh dananya

${ }_{9}^{9}$ Antonius dan RM Surachman Ombudsman Indonesia di Tengah Ombudsman Internasional sebuah Antologi, Komisi Ombudsman Nasional, Jakarta, 2002, hal. 78. 
bersumber dari anggaran pendapatan dan belanja Negara dan/atau anggran pendapatan dan belanja daerah.

Ombudsman adalah lembaga negara yang mempunyai kewenangan mengawasi penyelenggaraan pelayanan publik baik yang diselenggarakan oleh penyelenggara negara dan pemerintah dan memiliki kewenangan melakukan pemeriksaan-pemeriksaan tertentu khususnya yang terkait dengan dugaan adanya tindakan maladministrasi yang dilakukan oleh penyelenggara pemerintahan, penyelenggara negara, serta lembaga peradilan baik yang dilaporkan masyarakat ataupun atas inisiatif sendiri. Ombudsman merupakan Lembaga Negara mandiri, dalam menjalankan tugas dan wewenangnya bebas dari campur tangan kekuasaan lainnya (Pasal 2 UU No. 37 Tahun 2008). Pasal 3 UU No. 37 Tahun 2008, Ombudsman dalam menjalankan tugas dan wewenangnya berasaskan pada kepatutan, keadilan, non-diskriminasi, tidak memihak akuntabilitas, keseimbangan, keterbukaan dan kerahasiaan.

Pasal 35 Ayat (1) UU No. 25 Tahun 2009, Pengawasan penyelenggaraan pelayanan publik dilakukan oleh pengawas internal dan pengawas eksternal. Pengawasan internal penyelenggaraan pelayanan publik dilakukan melalui pengawasan oleh atasan langsung sesuai dengan peraturan perundang-undangan dan pengawasan oleh pengawas fungsional sesuai dengan peraturan perundang-undangan. Pengawasan eksternal penyelenggaraan pelayanan publik dilakukan melalui pengawasan oleh masyarakat berupa laporan atau pengaduan masyarakat dalam penyelenggaraan pelayanan publik, pengawasan oleh ombudsman sesuai dengan peraturan perundang-undangan dan pengawasan oleh Dewan Perwakilan Rakyat, Dewan Perwakilan Rakyat Daerah Provinsi, Dewan Perwakilan Rakyat Daerah Kabupaten/Kota.

Ombudsman Republik Indonesia Perwakilan Provinsi Kalimantan Utara dalam melakukan pengawasan terhadap pelayanan publik berwenang melakukan pengawasan terhadap penyelenggaraan pemerintahan dan pemerintah di wilayah Kalimantan Utara khusunya di Kota Tarakan dan menerima laporan atas dugaan maladministrasi dalam penyelenggaraan pelayanan publik. Pada masa pandemi COVID-19 di Kota Tarakan yang semakin meningkat dan PSBB terus diperpanjang oleh pemerintah mengakibatkan 
penyelenggara pelayanan publik terganggu dan tidak maksimal. Dalam upaya pencegahan pelanggaran dalam penyelenggaraan pelayanan publik, Ombudsman Perwakilan Kalimantan Utara melakukan koordinasi dan kerjasama dengan lembaga negara atau pemerintahan lainnya serta lembaga kemasyarakatan atau perseorangan. Seperti membangun jaringan kerja adalah salah satu tugas ombudsman dalam pelaksanaan pelayanan publik. Dan Ombudsman Perwakilan Kalimantan Utara melakukan koordinasi dan mempunyai beberapa program supervisi pelayanan publik, diantaranya terhadap beberapa instansi seperti Rumah Sakit Umum Daerah, Pusat Kesehatanan Masyarakat, Kantor Pelayanan Perizinan Terpadu, Dinas Kependudukan dan Catatan Sipil, Kantor UPT Samsat, Pelayanan di Lembaga Permasyarakatan/ Rumah Tahanan Negara, Pelayanan di Kantor Pertanahan, Pelayanan Pelabuhan, Pelayanan Bandar Udara dan Pelayanan di Kantor Imigrasi.

Sebagai upaya pencegahan maladministrasi dalam penyelenggaraan pelayanan publik, lembaga Ombudsman Perwakilan Kalimantan Utara melakukan supervisi terhadap penyelenggara pelayanan publik seperti: Rumah Sakit Umum Daerah, Pusat Kesehatanan Masyarakat, Kantor Pelayanan Perizinan Terpadu, Dinas Kependudukan dan Catatan Sipil, Kantor UPT Samsat, Pelayanan di Lembaga Permasyarakatan/Rumah Tahanan Negara, Pelayanan di Kantor Pertanahan, Pelayanan Pelabuhan, Pelayanan Bandar Udara, Pelayanan di Kantor Imigrasi dan Pelayanan di ruang terbuka seperti halaman resto/rumah makan maupun cafe. Dan melakukan sosialisasi dalam rangka meningkatkan kesadaran masyarakat atas hak pelayanan publik dengan strategi sosialisasi ditempatkan dimomen-momen apapun, kunjungan atau undangan menjadi pembicara pada suatu acara yang melibatkan masyarakat banyak dan webinar melalui media sosial selama social distancing.

Berdasarkan Surat Edaran Nomor 23 Tahun 2020 tentang Posko Pengaduan Daring Covid-19 Bagi Masyarakat terdampak Bencana Nasional Covid-19 Ombudsman Republik Indonesia. Surat Edaran ini adalah sebagai pedoman dalam melakukan pengawasan kebijakan layanan pemerintah bagi masyarakat dengan membuka saluran pengaduan daring (online) untuk melaporkan dugaan maladministrasi dalam pelaksanaannya. Secara 
internal, dengan Posko ini Ombudsman Republik Indonesia dapat memiliki data spesifik yang terpadu tentang keluhan publik untuk sektor-sektor terdampak COVID-19.

Ombudsman Perwakilan Kalimantan Utara juga Buka Posko Pengaduan Online bagi Warga Terdampak COVID-19. Sebagai lembaga pengawas pelayanan publik Ombudsman RI Paerwakilan Provinsi Kaltara membuka posko pengaduan daring (online) bagi masyarakat terdampak COVID-19 melalui tautan bit.ly/3f5diXO dan untuk mempermudah masyarakat menyampaikan pengaduan masyarakat dapat menyampaikan melalui aplikasi WhatsApp dinomor 08112743737. Jenis layanan yang dapat diadukan dan ditindaklanjuti melalui posko pengaduan COVID-19 Ombudsman meliputi layanan bantuan Jaring Pengaman Sosial (BLT atau bansos), layanan kesehatan, layanan lembaga keuangan, layanan transportasi, dan layanan keamanan. Bagi masyarakat yang terkena dampak COVID-19 dan merasa tidak mendapatkan pelayanan yang baik dapat segera melaporkan melalui kanal pengaduan yang telah disediakan dan setiap pelapor harus melampirkan fotokopi Kartu Tanda Penduduk (KTP), mengisi formulir pengaduan dan melampirkan dokumen pendukung, seperti foto, surat, dan lain-lain.

Laporan pengaduan yang masuk nantinya akan divalidasi untuk melihat kelengkapan persyaratannya. Laporan yang diterima akan ditindaklanjuti. ${ }^{10}$ Untuk laporan atau pengaduan yang ditindaklanjuti dengan mekanisme RCO, Ombudsman Republik Indonesia melakukan monitoring tindak lanjut sesuai Peraturan Ombudsman Nomor 26 Tahun 2017 tentang Tata Cara Penerimaan, Pemeriksaan dan Penyelesaian Laporan Masyarakat. Laporan atau pengaduan melalui kanal daring (online), koordinasi dilakukan dengan prosedur Posko Pengaduan Daring COVID-19 Ombudsman Republik Indonesia. Ombudsman Perwakilan Kalimantan Utara pada masa pandemi COVID-19 juga melakukan pemeriksaan mendadak (Sidak) dengan melakukan peninjauan secara langsung ke lapangan untuk meninjau secara langsung pelaksanaan pelayanan publik sesuai dengan standar pelayanan publik dan sesuai protokol kesehatan yang ada di Kota Tarakan. Obudsman RI Perwakilan Kaltara merimaan laporan atas dugaan maladministrasi dalam penyelenggaraan pelayanan publik pada masa pandemi COVID-19. Ombudsman

10 https://ombudsman.go.id/perwakilan/news/r/pwk--ombudsman-kaltara-buka-poskopengaduan-online-bagi-warga-terdampak-covid-19 
Perwakilan Provinsi Kalimantan Utara dalam melakukan pengawasan pelayanan publik pada masa Pandemi COVID-19 telah menerima sejumlah laporan terkait pelyanan publik. Subtansi laporan ada beberapa kategori pelaporan yaitu Belanja Jaring Pengaman Sosial, Pelayanan Medis bagi Korban Covid-19, Keuangan, Transportasi dan Keamanan.

Dari sejumlah laporan yang telah divalidasi dan dinyatakan memenuhi syarat, ditindaklanjuti dengan 2 (dua) cara yaitu diteruskan kepada instansi Kementerian/Lembaga/Pemerintah Daerah terkait melalui narahubung yang telah ditunjuk dan selanjutnya dimonitor tindakan selanjutnya. Dan dengan pola Respon Cepat Ombudsman (RCO). Keputusan untuk RCO ditetapkan oleh Anggota Pengampu Substansi atau Kepala Perwakilan setelah mendapatkan informasi dari narahubung masing-masing unit kerja. Tindak lanjut pengaduan dapat dilakukan secara lintas keasistenan di Ombudsman Republik Indonesia/Perwakilan Ombudsman melalui Tim Pengelola Pengaduan Daring Covid-19 Ombudsman Republik Indonesia. laporan yang diteruskan, Ombudsman Republik Indonesia melakukan monitoring tindak lanjut secara berskala dengan mekanisme yang disepakati dalam koordinasi dengan Kementerian/Lembaga/Pemerintah Daerah terkait.

Untuk laporan atau pengaduan yang ditindaklanjuti dengan mekanisme RCO, Ombudsman Republik Indonesia melakukan monitoring tindak lanjut seusai Peraturan Ombudsman Nomor 26 Tahun 2017 tentang Tata Cara Penerimaan, Pemeriksaan dan Penyelesaian Laporan Masyarakat. Ombudsman Republik Indonesia/Perwakilan Ombudsman memastikan Kementerian/Lembaga/Pemerintah Daerah selaku terlapor memberikan pemutakhiran data tindak lanjut penanganan laporan atau pengaduan kepada Ombudsman Republik Indonesia.

Penutupan laporan masyarakat dilakukan dengan mekanisme Peraturan Ombudsman Nomor 26 Tahun 2017 tentang Cara Penerimaan, Pemeriksaan dan Penyelesaian Laporan Masyarakat. Laporan akhir disusun pada akhir masa tugas Posko Pengaduan Daring Covid-19 Ombudsman Republik Indonesia, berisi rekap aduan, analisis aduan, hasil monitoring, dan saran Ombudsman Republik Indonesia. Laporan akhir disampaikan kepada Ketua Ombudsman Republik Indonesia serta Pimpinan Kementerian/Lembaga/Pemerintah Daerah. 
Berdasarkan hasil pengawasan yang dilakukan dan pemeriksaan oleh Ombudsman ditemukan pelanggaran pelayanan publik misalnya dibidang Pelayanan kesehatan, Pendidikan dan Bantuan Sosial. Hasil wawancara dengan bapak Bakuh Dwi Tanjung, dan data dari Ombudsman Perwakilan Kalimantan Utara, jumlah laporan terkait pelayanan publik masa pandemi COVID-19 di wilayah Kalimantan Utara khususnya Kota Tarakan yaitu sebagai berikut: ${ }^{11}$

Tabel. 1

\begin{tabular}{|c|c|c|c|}
\hline No. & Bidang Pelayanan & $\begin{array}{c}\text { Jumlah } \\
\text { Kasus }\end{array}$ & Waktu \\
\hline 1. & Pelayanan Bansos & 3 & April s/d Juli 2020 \\
\hline 2 & Pelayanan Kesehatan & 3 & Juni 2020 \\
\hline
\end{tabular}

Berdasarkan data diatas sejumlah laporan yang diterima kemudian dilakukan pemeriksaan substansi atas laporan ialah pemeriksaan lebih lanjut untuk mengetahui laporan masuk dalam kategori bantuan sosial, kesehatan. Hasil pemeriksaan yang dilakukan oleh Ombudsman Perwakilan Kalimantan Utara terhadap laporan yang diterima, sesuai tugas dan kewenangannya, yaitu setelah menerima laporan dan melalui tahap pemeriksaan substansi. Kemudian melakukan mediasi antara terlapor dengan pelapor. Setelah diadakan mediasi namun tidak menemukan solusi maka pihak ombudsman berwenang memberikan rekomendasi sesuai Pasal 8 ayat 1 UU No. 37 Tahun 2008 menyebutkan bahwa Ombudsman berwenang membuat rekomendasi mengenai penyeleseian laporan, termasuk rekomendasi untuk membayar ganti rugi dan/atau rehabilitasi kepada pihak yang dirugikan. Rekomendasi adalah kesimpulan, pendapat, dan saran yang disusun berdasarkan hasil investigasi ombudsman, kepada atasan terlapor untuk dilaksanakan dan/atau ditindaklanjuti dalam peningkatan mutu penyelenggaraan administrasi pemerintah yang baik. Ombudsman berhak melakukan investigasi terhadap perbuatan apparat pemerintah yang dilaporkan atau dikeluhkan oleh masyarakat atas dugaan maladministrasi dalam pelayanan publik atas prakasara sendiri diartikan bahwa melakukan investigasi atas prakarsa sendiri atau inisiatif ombudsman merupakan salah

11 Hasil wawancara dengan bapak Bakuh, selaku asisten I Ombudsman wilayah Kalimantan Utara, tanggal 10 September 2020 
satu cara untuk meningkatkan kinerja ombudsman. Dari hasil investigasi tersebut kemudian Ombudsman melakukan tindakan korektif dan mengeluarkan rekomendasi.

\section{KESIMPULAN}

Hasil dari penelitian ini kebijakan Pembatasan Sosial Berskala Besar melalui Peraturan Walikota Tarakan Nomor 17 Tahun 2020, pembatasan aktivitas dilur rumah seperti pelaksanaan pembelajaran di Sekolah dan/atau institusi pendidikan lainnya, Work FromHome (WFH), kegiatan keagamaan di rumah ibadah, kegiatan ditempat umum, kegiatan sosial dan budaya dan Wajib rapid test bagi yang menggunakan moda transportasi Laut dan Udara, dan memberikan bantuan sosial kepada masyarakat yang terdampak COVID-19.

Pengawasan Ombudsman terhadap pelayanan publik pada masa pandemi COVID-19 di Kota Tarakan yaitu dengan melakukan koordinasi dan Supervisi serta kerjasama dengan penyelenggara negara dan swasta serta lembaga kemasyarakatan atau perseorangan, membuka Posko Pengaduan Online bagi Warga Terdampak COVID-19. Juga melakukan pemeriksaan mendadak dalam rangka meningkatakan pelayanan publik di Kota Tarakan. Berdasarkan pengawasan, penerimaan laporan atas dugaan maladministrasi, dan hasil investigasi ombudsman dilakukan pemeriksaan. Apabila terbukti melakukan maladministrasi pelayanan publik, maka Ombudsman Republik Indonesia dapat melakukan tindakan korektif dan memberikan rekomendasi/saran kepada penyelenggara negara untuk meningkatan kualitas pelayanan publik.

\section{SARAN}

1. Kebijakan Pembatasan Sosial Berskla Besar (PSBB) untuk pencegahan penyebaran COVID-19 lebih luas namun untuk terlaksananya PSBB dengan efektif pemerintah menyediakan dan memenuhi kebutuhan masyarakat selama penerapan PSBB dan melakukan sosialisasi kebijakan PSBB, penerapan sanksi tegas kepada masyarakat yang melanggar PSBB.

2. Ombudsman sebagai lembaga yang mengawasi pelaksanaan pelayanan publik dalam melaksanakan tugasnya harus lebih aktif pada masa pandemi COVID-19 seperti saat ini karena banyak keluhan dari masyarakat terkait pelayanan publik namun manyarakat 
enggan untuk melapor kepada ombudsman walaupun sudah membuka layanan secara daring (online).

\section{DAFTAR PUSTAKA}

\section{Buku-buku:}

Abdul Rasyid Thalib, Wewenang Mahkamah Konstitusi dan Aplikasinya dalam Sistem Ketatanegaraan Republik Indonesia, Citra Aditya Bakti Bandung. 2006.

Antonius dan RM Surachman Ombudsman Indonesia di Tengah Ombudsman Internasional sebuah Antologi, Komisi Ombudsman Nasional, Jakarta. 2002.

Fadhilah, N. L. Urgensitas Ombudsman Dalam Pengawasan Pelayanan Publik. Jurnal Ilmiah Pendidikan Pancasila dan Kewarganegaraan. 2016.

Hidjaz, M. K. Efektivitas penyelenggaraan kewenangan dalam sistem pemerintahan daerah di Indonesia. Pustaka Refleksi. 2010

Hani Handoko, Manajemen Personalia dan Sumber Daya Manusia. Jakarta: PT Rafika Aditam. 1999.

Hakim, L. Kewenangan organ negara dalam penyelenggaraan pemerintahan. Jurnal Konstitusi, 4(1). 2011

HR, Ridwan. Hukum Administrasi Negara. Jakarta. Rajawali Pers. 2010.

Husni Thamrin, Hukum Pelayanan Publik di Indonesia, Aswaja Pressindo, Yogyakarta. 2013.

Islamy, Prinsip-prinsip Perumusan Kebijakan Negara, Bumi Aksara, Jakarta. 1997.

Kamal hidjaz, Efektivitas Penyelenggaraan Kewenangan dalam Sistem Pemerintahan Daerah di Indonesia, Pustaka Refleksi, Makasar. 2010.

Lutfi Efendi, Pokok-pokok Hukum Administrasi Negara, Bayumedia, Malang, 2004.

Moenir. Manajemen Pelayanan Umum di Indonesia. Jakarta: Bumi Aksara. 2010.

Neng Kamarmi, S. M. Analisis Pelayanan Publik Terhadap Masyarakat (Kasus Pelayanan Kesehatan Di Kabupaten Agam). Jurnal Manajemen dan Kewirausahaan, 2. 2011.

Makmur, Efektivitas Kebijakan Pengawasan. Bandung PT. Refika Aditama. 2011.

Neng Kamarni, "Analisis Pelayanan Publik terhadap Masyarakat (Kasus Pelayanan Kesehatan di Kabupaten Agam)" Jurnal Manajemen dan KewirausahaanUniversitas Andalas Padang, Volume 2, Nomor 3

Peter Mahmud Marzuki Penelitian Hukum, Jakarta: Prenadamedia Group. 2016. 
Prajudi Atmosudirdjo, Hukum Administrasi Negara, Ghalia Indonesia, Jakarta, 1994.

Sahya Anggara, Kebijakan Publik, Pustaka Setia, Bandung. 2014.

S.F. Marbun, Peradilan Administrasi Negara dan Upaya Administratif di Indonesia, Liberty, Yogyakarta, 1997.

Syaâ, M. I. Kedudukan dan Kewenangan Ombudsman Republik Indonesia dalam Mengawasi Penyelenggaraan Pelayanan Publik. Al-Daulah: Jurnal Hukum dan Perundangan Islam, 2015.

Syaâ, M. IKedudukan dan Kewenangan Ombudsman Republik Indonesia dalam Mengawasi Penyelenggaraan Pelayanan Publik. Al-Daulah: Jurnal Hukum dan Perundangan Islam, 5(1) 2015.

Yulianto, Y. Meningkatkan Kompetensi Aparatur Sipil Negara Dalam Pelayanan Publik Menuju Era New Normal. In Prosiding Seminar STIAMI (Vol. 7, No. 2, pp. 36-45). 2020.

\section{Peraturan Perundang-Undangan:}

Undang-Undang Dasar Negara Republic Indonesia Tahun 1945.

Undang-Undang Nomor 37 Tahun 2008 tentang Ombudsman RepubliK Indonesia.

Undang-Undang Nomor 25 Tahun 2009 tentang Pelayanan Publik.

Undang-UndangNomor 5 Tahun 2014 tentang Aparatur Sipil Negara.

Undang-Undang Nomor 23 Tahun 2014 Tentang Pemerintah Daerah

Undang-Undang Nomor 30 Tahun 2014 Tentang Administrasi Pemerintahan.

Peraturan Pemerintah Nomor 96 Tahun 2012 tentang Peraturan Pelaksana Undang_undang Nomor 25 Tahun 2009 tentang Pelayanan Publik.

Undang Nomor 6 Tahun 2018 tentang Kekarantinaan Kesehatan.

Undang-Undang Nomor 36 Tahun 2009 tentang Kesehatan.

Undang-Undang Nomor 4 Tahun 1984 tentang Wabah Penyakit Menular.

Peraturan Pemerintah Nomor 21 Tahun 2020 tentang Pembatasan Sosial Berskala Besar

Dalam Rangka Percepatan Penanganan Corona Virus Disease 2019 (COVID-19). 
Peraturan Wali Kota Nomor 17 Tahun 2020 tentang Pelaksanaan Pembatasan Sosial Berskala Besar Dalam rangka percepatan Penanganan Corona Virus Disease 2019 (COVID-19) di Kota Tarakan.

Keputusan Menteri Kesehatan Republik Indonesia Nomor HK.01.07 /MENKES/261/2020 tentang Penetapan Pembatasan Sosial Berskala Besar diwilayah Kota Tarakan Provinsi Kalimantan Utara dalam rangka percepatan penanganan Corona Virus Disease 2019 (COVID-19).

Surat Edaran Nomor 23 Tahun 2020 tentang Posko Pengaduan Daring Covid19 Bagi Masyarakat Terdampak Bencana Nasional Covid19 Ombudsman Republik Indonesia.

Pedoman Umum Menghadapi Pandemi Covod-19 Bagi Pemerintah Daerah Pencegahan, Pengendalian, Diagnosis dan Managemen dari Kemeterian Dalam Negeri Untuk Dukungan Gugus Tugas Covid-19.

\section{Webesite:}

http://www.negarahukum.com/hukum/teoripengawasan.html

https://www.covid19.go.id/

https://ombudsman.go.id/perwakilan/news/r/pwk--ombudsman-kaltara-buka-poskopengaduan-online-bagi-warga-terdampak-covid-19

https://www.suara.com/video/2020/03/31/152117/live-streaming-konferensi-perspresiden-joko-widodo-soal-darurat-sipi 